\title{
STRATEGI PEMBELAJARAN UNTUK MENINGKATKAN \\ KEMAMPUAN PEMECAHAN MASALAH GEOMETRI BAGI MAHASISWA YANG MENGALAMI PROBLEMA BELAJAR DI STAIN PALOPO (STUDI TENTANG APLIKASI TEORI BELAJAR POLYA)
}

\author{
Oleh: ${ }^{1}$ Nur Rahmah, ${ }^{2}$ Muhammad Hajarul Aswad A \\ 1,2 Program Studi Pendidikan Matematika Fakultas Tarbiyah STAIN Palopo \\ e-mail: ${ }^{1}$ nurrahmah 85@yahoo.co.id dan ${ }^{2}$ as wad82@yahoo.co.id
}

\begin{abstract}
Abstrak:
Masalah dalam penelitian ini adalah bagaimana strategi pembelajaran pemecahan masalah Polya kaitannya dengan mahasiswa yang mengalami problema belajar, desain didaktis teori belajar Polya dalam pembelajaran geometri khususnya konsep luas segitiga dan segiempat, serta respon mahasiswa terhadap strategi pembelajaran yang diberikan. Jenis penelitian yang dilakukan adalah penelitian kualitatif naturalistik. Subjek dalam penelitian ini adalah seluruh mahasiswa matematika semester II STAIN Palopo Tahun Akademik 20132014 yang mengalami problema belajar pada mata kuliah geometri yang tersebar ke dalam 3 kelas (A, B, dan C) berjumlah 18 orang.Teknik pengumpulan data yang dilakukan dengan menggunakan angket, dan observasi. Sedangkan teknik analisis datanya menggunakan analisis deskriptif. Hasil penelitian menunjukkan bahwa kemampuan mahasiswa dalam menyelesaikan masalah terkait dengan konsep luas segitiga dan segiempat pada dasarnya sudah bagus. Akan tetapi masih ada beberapa langkah yang belum sistematis. Pada saat observasi pertama dilakukan terlihat bahwa kemampuan mahasiswa dalam memahami masalah yang diberikan berbeda-beda berdasarkan kerangka kerja Polya. Selanjutnya pada tahap membuat rencana pemecahan masalah kemampuan mahasiswa juga berbeda berdasarkan tingkatan kerja dalam rencana pemecahan masalah yang diberikan. Pada pembelajaran berikutnya telah dikemukakan kepada mahasiswa bentuk kerangka kerja pemecahan masalah Polya sehingga ketika diberikan masalah terkait dengan konsep luas segitiga dan segiempat, kemampuan mahasiswa dalam memecahkan masalah berangsur-angsur lebih sistematis berdasarkan kerangka kerja yang telah diberikan. Hal ini dimaksudkan untuk mengarahkan mahasiswa yang mengalami problema belajar bahwa memecahkan masalah harus dengan langkah-langkah yang sistematis.
\end{abstract}

Kata Kunci: Strategi Pembelajaran, Teori Belajar Polya

\section{Pendahuluan}

\section{A. Latar Belakang Masalah}

Belajar merupakan proses perubahan tingkah laku yang relatif tetap. Dalam proses ini perubahan tidak terjadi sekaligus tetapi terjadi secara bertahap tergantung pada faktor-faktor pendukung belajar yang mempengaruhi mahasiswa. Faktor-faktor ini umumnya dapat dibagi menjadi dua kelompok yaitu faktor intern dan faktor ekstern. Faktor intern berhubungan dengan segala sesuatu yang ada pada diri mahasiswa yang menunjang 
pembelajaran, seperti inteligensi, bakat, kemampuan motorik pancaindra, dan skema berpikir. Faktor ekstern merupakan segala sesuatu yang berasal dari luar diri mahasiswa yang mengkondisikannya dalam pembelajaran, seperti pengalaman, lingkungan sosial, metode belajar-mengajar, strategi belajarmengajar, fasilitas belajar dan dedikasi pengajar. Keberhasilannya mencapai suatu tahap hasil belajar memungkinkannya untuk belajar lebih lancar dalam mencapai tahap selanjutnya (Suherman, 2003:25).

Dari banyak bahasan dalam matematika, geometri merupakan satu bahasan yang memiliki keterkaitan konsep yang tinggi. Geometri menempati posisi khusus dalam kurikulum matematika karena banyaknya konsep-konsep yang termuat didalamnya. Dari sudut pandang psikologi, geometri merupakan penyajian abstraksi dari pengalaman visual misalnya bidang, pola, pengukuran dan pemetaan. Sedangkan dari sudut pandang matematik, geometri menyediakan pendekatan-pendekatan untuk pemecahan masalah, misalnya gambar-gambar, diagram, system koordinat, vekror, dan transformasi. Geometri juga merupakan sarana untuk mempelajari struktur matematika.

Memecahkan suatu masalah merupakan suatu aktivitas dasar bagi manusia. Kenyataan menunjukkan, sebagian besar kehidupan kita adalah berhadapan dengan masalah-masalah. Kita perlu mencari penyelesaiannya. Bila kita gagal dengan suatu cara untuk menyelesaikan suatu masalah. Kita harus mencoba menyelesaiakannya dengan cara lain dan harus berani menghadapi masalah untuk menyelesaiakannya(Abidin Z, 1989: 5).

Pertanyaan-pertanyaan di atas tidak mudah dijawab. Oleh karena itu, pada penelitian ini dikemukakan salah satu pendekatan pembelajaran matematika yang dapat digunakan, yaitu pendekatan pemecahan masalah matematika. Pendekatan ini dipilih karena karakteristiknya yang membiasakan mahasiswa pada proses berpikir tingkat tinggi. Melalui proses berpikir tingkat tinggi, mahasiswa dibiasakan untuk melakukan suatu proses berpikir tentang penyelesaian suatu masalah dengan menggunakan langkahlangkah penyelesaian masalah yang benar dan logis.

Berdasarkan uraian tersebut di atas, maka peneliti mencoba untuk melakukan penelitian dengan judul: "Strategi pembelajaran untuk meningkatkan kemampuan pemecahan masalah geometri bagi mahasiswa yang mengalami problema belajar pada mahasiswa semester II matematika STAIN Palopo. (studi tentang aplikasi teori belajar Polya)". 
65 | al-Khwarizmi, Volume III, Edisi 1, Maret 2015, Hal. 63 - 82.

B. Tujuan

Tujuan dalam penelitian ini adalah untuk mengetahui:

1. Strategi pembelajaran terkait kemampuan pemecahan masalah geometri mahasiswa semester II matematika STAIN Palopo;

2. Desain didaktis teori belajar Polya untuk meningkatkan kemampuan pemecahan masalah geometri mahasiswa semester II matematika STAIN Palopo;

3. Respon mahasiswa yang mengalami problema belajar terkait implementasi strategi pembelajaran yang diberikan.

C. Pembatasan Masalah

Agar fokus dalam penelitian ini, maka peneliti membatasi permasalahan di atas pada hal-hal berikut:

1. Strategi pembelajaran yang digunakan dalam penelitian ini adalah menggunakan teori belajar Polya

2. Problema belajar yang dimaksud adalah kesulitan dalam memahami dan memecahkan soal yang terkait dengan geometri khusunya konsep Luas Segitiga dan Segiempat.

3. Desain teori belajar yang digunakan mengikuti langkah-langkah pemecahan masalah Polya.

\section{Kajian Pustaka}

A. Kajian Riset Sebelumnya

Penelitian terdahulu yang relevan dengan penelitian ini adalah:

1. Penelitian yang dilakukan oleh Arum Handini Primandari (2010) yang berjudul: Upaya Meningkatkan Kemampuan Pemecahan Masalah Siswa Kelas VIIIA SMP N 2 Nanggulan dalam Pembelajaran Matematika Pokok Bahasan Bangun Ruang Menggunakan Model Pembelajaran Kooperatif Tipe Think-Pair-Square.Penelitian ini bertujuan untuk meningkatkan kemampuan pemecahan masalah siswa kelas VIIIA SMP N 2 Nanggulan dalam pembelajaran matematika menggunakan model pembelajaran kooperatif tipe Think-Pair-Square. Kemampuan pemecahan masalah meliputi 4 aspek, yaitu kemampuan memahami masalah, kemampuan merencanakan penyelesaian masalah, kemampuan menyelesaikan masalah, dan kemampuan menafsirkan solusi yang diperoleh.(Arum Handini Primandari, 2010).

2. Penelitian yang kedua dilakukan oleh Muhtarom (2012). Penelitian ini berjudul Profil Kemampuan Pemecahan Masalah Mahasiswa yang Mempunyai Gaya kognitif field independen (FI) pada mata kuliah kalkulus. Hasil penelitian ini 
menunjukkan bahwa jelas dalam menuliskan apa yang ditanyakan, dapat dengan mudah dan benar menuliskan apa yang diketahui pada masalah, dapat membuatr kaitan antara hal yang diketahui dan hal yang ditanyakan.(Muhtarom, 2012).

Berbeda dengan penelitian yang akan peneliti lakukan. Penelitian ini menekankan pada aspek desain didaktis teori pemecahan masalah polya bagi mahasiswa yang mengalami problema belajar pada materi geometri khususnya konsep luas segitiga dan luas segiempat. Peneliti ingin mengetahui sejauh mana aplikasi teori belajar polya mampu meningkatkan kemampuan pemcahan masalah bagi mahasiswa yang mengalami problema belajar.

\section{B. Pemecahan Masalah dalam Pembelajaran Matematika Menurut Polya}

Polya (1985) mengartikan pemecahan masalah sebagai satu usahamencari jalan keluar dari satu kesulitan guna mencapai satu tujuan yang tidakbegitu mudah segera untuk dicapai, pemecahan masalah dapat berupamenciptakan ide baru, menemukan teknik atau produk baru. Bahkan didalampembelajaran matematika, selain pemecahan masalah mempunyai arti khusus, istilah tersebut mempunyai interpretasi yang berbeda, misalnya menyelesaikansoal cerita yang tidak rutin dan mengaplikasikan matematika dalam kehidupansehari-hari.Polya(1985) mengajukan empat langkah fase penyelesaian masalahyaitu memahami masalah, merencanakan penyelesaian, menyelesaikan masalah dan melakukan pengecekan kembali semua langkah yang telah dikerjakan (Polya George, 1985).

\section{Perencanaan Mengajarkan Pemecahan Masalah}

Mengajar mahasiswa untuk memecahkan masalah perlu perencanaan. Secaragarisbesar, perencanaan itu sebagai berikut:

1) Merumuskan tujuan.

2) Memerlukan pra-syarat.

3) Mengajarkan Pemecahan Masalah.

D. Langkah-langkah Penerapan strategi penyelesaian masalah menurutPolya.

Berbicara pemecahan masalah, kita tidak bisa terlepas dari tokoh utamanyayaitu Polya. Menurut polya dalam pemecahan masalah. Ada empat langkah yangharus dilakukan,Keempat tahapan ini lebih dikenal dengan See (memahami problem), Plan(menyusun rencana), Do (melaksanakan rencana) dan Check (menguji jawaban),sudah menjadi jargon sehari-hari dalam 
67|al-Khwarizmi, Volume III, Edisi 1, Maret 2015, Hal. 63 - 82. penyelesaian problem sehingga Polyalayak disebut dengan "Bapak problem solving."'Gambaran umum dari Kerangka kerja Polya:

1) Pemahaman pada masalah (Identifikasi dari tujuan)

2) Membuat Rencana Pemecahan Masalah

3) Ketiga. Menyelesaikan rencana anda.

4) Lihatlah kembali (Polya George, 1985).

E. Jenis-Jenis Kesulitan Belajar

Kesulitan belajar siswa mencakup pengertian yang luas, diantaranya : (a) learning disorder; (b) learning disfunction; (c) underachiever; (d) slow learner, dan (e) learning diasbilities. Di bawah ini akan diuraikan dari masing-masing pengertian tersebut. (Udin S Winataputra, dkk; 2003: 79).

Beberapa perilaku yang merupakan manifestasi gejala kesulitan belajar, antara lain :

1) Menunjukkan hasil belajar yang rendah di bawah rata-rata nilai yang dicapai oleh kelompoknya atau di bawah potensi yang dimilikinya.

2) Hasil yang dicapai tidak seimbang dengan usaha yang telah dilakukan. Mungkin ada mahasiswa yang sudah berusaha giat belajar, tapi nilai yang diperolehnya selalu rendah

3) Lambat dalam melakukan tugas-tugas kegiatan belajarnya dan selalu tertinggal dari kawan-kawannya dari waktu yang disediakan.

4) Menunjukkan sikap-sikap yang tidak wajar, seperti: acuh tak acuh, menentang, berpura-pura, dusta dan sebagainya.

5) Menunjukkan perilaku yang berkelainan, seperti membolos, datang terlambat, tidak mengerjakan pekerjaan rumah, mengganggu di dalam atau pun di luar kelas, tidak mau mencatat pelajaran, tidak teratur dalam kegiatan belajar, dan sebagainya.

6) Menunjukkan gejala emosional yang kurang wajar, seperti : pemurung, mudah tersinggung, pemarah, tidak atau kurang gembira dalam menghadapi situasi tertentu. Misalnya dalam menghadapi nilai rendah, tidak menunjukkan perasaan sedih atau menyesal, dan sebagainya. (W Gulo, 2005:90).

\section{Metode Penelitian}

A. Jenis penelitian

Jenis penelitian yang dilakukan adalah penelitian kualitatif naturalistik. Istilah naturalistik menunjukkan bahwa pelaksanaan penelitian ini memang terjadi secara alamiah, apa adanya, dalam situasi normal yang tidak dimanipulasi keadaan dan kondisinya, 
menekankan pada deskripsi secara alami. (Suharsimi Arikunto, 2006: 12).

\section{B. Lokasi penelitian}

Lokasi penelitian ini dikampus STAIN Palopo Jalan Agatis Kelurahan Balandai Kecamatan Bara Kota Palopo tepatnya di Prodi Pendidikan Matematika.

\section{Subjek penelitian}

Subjek dalam penelitian ini adalah seluruh mahasiswa matematika semester II STAIN Palopo Tahun Akademik 20132014 yang mengalami problema belajar pada mata kuliah geometri. Informasi tersebut diperoleh dari dosen yang mengampuh mata kuliah tersebut yang didasarkan pada nilai matakuliah. Jadi subjek dalam penelitian ini tersebar ke dalam 3 kelas (A, B, dan C) berjumlah 18 orang.

\section{Teknik pengumpulan data}

Teknik pengumpulan data yang dilakukan dengan menggunakan angket, dan observasi. Angket digunakan untuk melihat respon mahasiswa terkait dengan strategi yang dilakukan. Sedangkan lembar observasi aktivitas mahasiswa digunakan untuk mengamati aktivitas mahasiswa terkait dengan langkah-langkah pemecahan masalah Polya.

\section{E. Teknik Pengolahan dan Analisis data}

1. Analisis Validitas Instrumen

Validitas isi dapat dibantu dengan menggunakan kisi-kisi instrumen. Dalam kisi-kisi itu terdapat variabel yang diteliti, indikator sebagai tolak ukur dan nomor butir (item) pertanyaan atau pernyataan yang telah dijabarkan dalam indikator. Dengan kisi-kisi instrumen itu maka pengujian validitas dapat dilakukan dengan mudah dan sistematis.(Sugiyono, 2012: 182).

2. Analisis Data dengan Statistik Deskriptif

Data yang diperoleh dalam penelitian ini dianalisis secara deskriptif untuk mendeskripsikan strategi pemecahan masalah Polya yang digunakan. Hasil analisa tersebut ditampilkan dalam bentuk desain didaktis teori belajar Polya.

\section{Hasil Penelitian}

\section{A. Hasil Penelitian}

Berdasarkan penelitian yang telah dilakukan, diperoleh data hasil penelitian. Data ini kemudian dianalisis untuk mendapatkan kesimpulan dari hasil penelitian. Analisis data ini berupa analisis validitas instrumen dan analisis data hasil penelitian.

1. Hasil Analisis Validitas instrumen 
69 | al-Khwarizmi, Volume III, Edisi 1, Maret 2015, Hal. 63 - 82.

\begin{tabular}{|c|c|c|c|}
\hline $\begin{array}{l}\mathbf{N} \\
\mathbf{0}\end{array}$ & Aspek yang dinilai & $\begin{array}{c}\text { Frekuensi } \\
\text { Penilaian } \\
1234\end{array}$ & Ket. \\
\hline 1 & $\begin{array}{l}\text { Materi } \\
\text { a. Instrumen sesuai dengan indikator } \\
\text { b. Batasan dan ruang lingkup yang akan diukur sudah jelas } \\
\text { c. Isi materi yang diberikan sesuai dengan tujuan pembelajaran }\end{array}$ & $\begin{array}{l}4 \\
4 \\
3\end{array}$ & Valid \\
\hline 2 & $\begin{array}{l}\text { Konstruksi } \\
\text { Rumusan butir instrumen tidak menimbulkan penafsiran ganda }\end{array}$ & 4 & Valid \\
\hline 3 & $\begin{array}{l}\text { Bahasa } \\
\text { a. Rumusan butir instrumen menggunakan bahasa yang sederhana } \\
\text { dan mudah dipahami } \\
\text { b. Menggunakan istilah yang mudah dikenal mahasiswa. } \\
\text { c. Rumusan butir instrumen menggunakan bahasa Indonesia yang } \\
\text { baik dan benar }\end{array}$ & $\begin{array}{l}4 \\
4 \\
4\end{array}$ & Valid \\
\hline
\end{tabular}

Berdasarkan tabel 4.1 di atas dapat dikatakan bahwa instrumen yang digunakan valid berdasarkan kategori validitasnya.

2. Analisis statistik deskriptif aktivitas mahasiswa terkait strategi pembelajaran Polya

a. Analisis deskriptif aktivitas mahasiswa yang mengalami problema belajar

Hasil analisis deskriptif strategi pembelajaran Polya terkait dengan observasi aktivitas mahasiswa yang mengalami problema belajar digambarkan dalam tabel di bawah ini:

Tabel 4.2: Lembar observasi aktivitas mahasiswa yang mengalami problema belajar pada mata kuliah geometri semester IIA

\begin{tabular}{|c|l|c|c|c|c|c|c|c|c|}
\hline \multirow{3}{*}{ No } & \multirow{2}{*}{ Nama Mahasiswa } & \multicolumn{7}{|c|}{ Aktivitas Mahasiswa Ke- } & \multirow{2}{*}{ Ket } \\
\cline { 3 - 11 } & & $\mathbf{5}$ & $\mathbf{1 0}$ & $\mathbf{1 5}$ & $\mathbf{2 0}$ & $\mathbf{2 5}$ & $\mathbf{3 0}$ & $\mathbf{3 5}$ & \\
\hline 1 & Eni Wijayanti & $1 \mathrm{a}$ & $1 \mathrm{c}$ & $2 \mathrm{a}$ & $2 \mathrm{~b}$ & $2 \mathrm{~d}$ & 3 & 4 & \\
\hline 2 & Vini Alvionita & $1 \mathrm{a}$ & $1 \mathrm{~b}$ & $2 \mathrm{~b}$ & $2 \mathrm{~b}$ & $2 \mathrm{e}$ & 3 & 4 & \\
\hline 3 & Mutmainna & $1 \mathrm{a}$ & $1 \mathrm{~d}$ & $2 \mathrm{a}$ & $2 \mathrm{c}$ & $2 \mathrm{e}$ & 3 & 4 & \\
\hline 4 & Suraidah Ahmadi & $1 \mathrm{a}$ & $1 \mathrm{~d}$ & $2 \mathrm{a}$ & $2 \mathrm{~b}$ & $2 \mathrm{e}$ & 3 & 4 & \\
\hline 5 & Ermawati & $1 \mathrm{a}$ & $1 \mathrm{~b}$ & $2 \mathrm{~b}$ & $2 \mathrm{e}$ & $2 \mathrm{~g}$ & 3 & 4 & \\
\hline 6 & Aira Ulan Dari & $1 \mathrm{a}$ & $1 \mathrm{~b}$ & $2 \mathrm{~d}$ & $2 \mathrm{e}$ & $2 \mathrm{~g}$ & 3 & 4 & \\
\hline
\end{tabular}

Tabel 4.3: Lembar observasi aktivitas mahasiswa yang mengalami problema belajar pada mata kuliah geometri semester IIB

\begin{tabular}{|c|l|c|c|c|c|c|c|c|c|}
\hline \multirow{2}{*}{ No } & \multirow{2}{*}{ Nama Mahasiswa } & $\mathbf{5}$ & $\mathbf{1 0}$ & $\mathbf{1 5}$ & $\mathbf{2 0}$ & $\mathbf{2 5}$ & $\mathbf{3 0}$ & $\mathbf{3 5}$ & \multirow{2}{*}{ Ket. } \\
\cline { 3 - 11 } & & 1a & $1 \mathrm{~d}$ & $2 \mathrm{a}$ & $2 \mathrm{c}$ & $2 \mathrm{~g}$ & 3 & 4 & \\
\hline 1 & Hasdalipa & $1 \mathrm{a}$ & $1 \mathrm{c}$ & $2 \mathrm{a}$ & $2 \mathrm{~d}$ & $2 \mathrm{e}$ & 3 & 4 & \\
\hline 2 & Jumarni & $1 \mathrm{a}$ & $1 \mathrm{~d}$ & $2 \mathrm{~b}$ & $2 \mathrm{c}$ & $2 \mathrm{~g}$ & 3 & 4 & \\
\hline 3 & Hasna & $1 \mathrm{a}$ & $1 \mathrm{~d}$ & $2 \mathrm{c}$ & $2 \mathrm{~d}$ & $2 \mathrm{f}$ & 3 & 4 & \\
\hline 4 & Nur Oktaviani & $1 \mathrm{a}$ & $1 \mathrm{~b}$ & $2 \mathrm{c}$ & $2 \mathrm{~d}$ & $2 \mathrm{~g}$ & 3 & 4 & \\
\hline 5 & Hisdar & $1 \mathrm{a}$ & $1 \mathrm{~b}$ & $2 \mathrm{a}$ & $2 \mathrm{~b}$ & $2 \mathrm{~g}$ & 3 & 4 & \\
\hline 6 & Indra Purnama Jaya & \multicolumn{1}{|c|}{} & & & & & & \\
\hline
\end{tabular}


Strategi Pembelajaran untuk ... $\mathbf{7 0}$

Tabel 4.4 : Lembar observasi aktivitas mahasiswa yang mengalami problema belajar pada mata kuliah geometri semester IIC

\begin{tabular}{|c|l|c|c|c|c|c|c|c|c|}
\hline \multirow{2}{*}{ No } & \multirow{2}{*}{ Nama Mahasiswa } & \multicolumn{6}{|c|}{ Aktivitas Mahasiswa Menit Ke- } & \multirow{2}{*}{ Ket. } \\
\cline { 3 - 10 } & & $\mathbf{5}$ & $\mathbf{1 0}$ & $\mathbf{1 5}$ & $\mathbf{2 0}$ & $\mathbf{2 5}$ & $\mathbf{3 0}$ & $\mathbf{3 5}$ & \multirow{2}{*}{} \\
\hline 1 & Sudarmin & $1 \mathrm{a}$ & $1 \mathrm{~b}$ & $2 \mathrm{~b}$ & $2 \mathrm{~d}$ & $2 \mathrm{~h}$ & 3 & 4 & \\
\hline 2 & Muh.Hanafi & $1 \mathrm{a}$ & $1 \mathrm{~b}$ & $2 \mathrm{~b}$ & $2 \mathrm{c}$ & $2 \mathrm{~g}$ & 3 & 4 & \\
\hline 3 & Sahariana & $1 \mathrm{a}$ & $1 \mathrm{~b}$ & $2 \mathrm{~d}$ & $2 \mathrm{e}$ & $2 \mathrm{~h}$ & 3 & 4 & \\
\hline 4 & Muh.Said Bahru & $1 \mathrm{a}$ & $1 \mathrm{c}$ & $2 \mathrm{~b}$ & $2 \mathrm{e}$ & $2 \mathrm{f}$ & 3 & 4 & \\
\hline 5 & Ummi Kalsum & $1 \mathrm{a}$ & $2 \mathrm{a}$ & $2 \mathrm{~b}$ & $2 \mathrm{e}$ & $2 \mathrm{~g}$ & 3 & 4 & \\
\hline 6 & Sugiarti & $1 \mathrm{a}$ & $1 \mathrm{~b}$ & $2 \mathrm{~b}$ & $2 \mathrm{c}$ & $2 \mathrm{e}$ & 3 & 4 & \\
\hline
\end{tabular}

b. Analisis deskriptif strategi pemecahan masalah Polya

Hasil analisis deskriptif terkait strategi pemecahan masalah Polya bagi mahasiswa yang mengalami problema belajar digambarkan pada tabel berikut ini:

Tabel 4.5 : Lembar observasi aktivitas mahasiswa terkait strategi pemecahan masalah Polya pada mata kuliah geometri semester IIA

\begin{tabular}{|c|l|c|c|c|c|c|c|c|c|}
\hline \multirow{2}{*}{ No } & \multirow{2}{*}{ Nama Mahasiswa } & $\mathbf{5}$ & $\mathbf{1 0}$ & $\mathbf{1 5}$ & $\mathbf{2 0}$ & $\mathbf{2 5}$ & $\mathbf{3 0}$ & \multirow{3}{*}{ 35 } & \multirow{2}{*}{ Ket. } \\
\cline { 3 - 11 } & & & & & & & & \\
\hline 1 & Eni Wijayanti & $1(\mathrm{a}, \mathrm{b})$ & $1(\mathrm{c}, \mathrm{d})$ & $2(\mathrm{a}, \mathrm{b}, \mathrm{c})$ & $2(\mathrm{~d}, \mathrm{e})$ & $2(\mathrm{f}, \mathrm{g}, \mathrm{h})$ & 3 & 4 & \\
\hline 2 & Vini Alvionita & $1(\mathrm{a}, \mathrm{b})$ & $1(\mathrm{c}, \mathrm{d})$ & $2(\mathrm{a}, \mathrm{b}, \mathrm{c})$ & $2(\mathrm{~d}, \mathrm{e})$ & $2(\mathrm{f}, \mathrm{g}, \mathrm{h})$ & 3 & 4 & \\
\hline 3 & Mutmainna & $1(\mathrm{a}, \mathrm{b})$ & $1(\mathrm{c}, \mathrm{d})$ & $2(\mathrm{a}, \mathrm{b}, \mathrm{c})$ & $2(\mathrm{~d}, \mathrm{e})$ & $2(\mathrm{f}, \mathrm{g}, \mathrm{h})$ & 3 & 4 & \\
\hline 4 & Suraidah Ahmadi & $1(\mathrm{a}, \mathrm{b})$ & $1(\mathrm{c}, \mathrm{d})$ & $2(\mathrm{a}, \mathrm{b}, \mathrm{c})$ & $2(\mathrm{~d}, \mathrm{e})$ & $2(\mathrm{f}, \mathrm{g}, \mathrm{h})$ & 3 & 4 & \\
\hline 5 & Ermawati & $1(\mathrm{a}, \mathrm{b})$ & $1(\mathrm{c}, \mathrm{d})$ & $2(\mathrm{a}, \mathrm{b}, \mathrm{c})$ & $2(\mathrm{~d}, \mathrm{e})$ & $2(\mathrm{f}, \mathrm{g}, \mathrm{h})$ & 3 & 4 & \\
\hline 6 & Aira Ulan Dari & $1(\mathrm{a}, \mathrm{b})$ & $1(\mathrm{c}, \mathrm{d})$ & $2(\mathrm{a}, \mathrm{b}, \mathrm{c})$ & $2(\mathrm{~d}, \mathrm{e})$ & $2(\mathrm{f}, \mathrm{g}, \mathrm{h})$ & 3 & 4 & \\
\hline
\end{tabular}

Tabel 4.6: Lembar observasi aktivitas mahasiswa terkait strategi pemecahan masalah Polya pada mata kuliah geometri semester IIB

\begin{tabular}{|c|c|c|c|c|c|c|c|c|c|}
\hline \multirow[b]{2}{*}{ No } & \multirow[b]{2}{*}{ Nama Mahaiswa } & \multicolumn{7}{|c|}{ Aktivitas Mahasiswa Menit Ke- } & \multirow[b]{2}{*}{ Ket. } \\
\hline & & 5 & 10 & 15 & 20 & 25 & 30 & 35 & \\
\hline 1 & Hasdalipa & $1(\mathrm{a}, \mathrm{b})$ & $1(\mathrm{c}, \mathrm{d})$ & $2(a, b)$ & $2(\mathrm{c}, \mathrm{d}, \mathrm{e})$ & $2(\mathrm{f}, \mathrm{g}, \mathrm{h})$ & 3 & 4 & \\
\hline 2 & Jumarni & $1(\mathrm{a}, \mathrm{b})$ & $1(\mathrm{c}, \mathrm{d})$ & $2(a, b)$ & $2(\mathrm{c}, \mathrm{d}, \mathrm{e})$ & $2(f, g, h)$ & 3 & 4 & \\
\hline 3 & Hasna & $1(\mathrm{a}, \mathrm{b})$ & $1(\mathrm{c}, \mathrm{d})$ & $2(a, b)$ & $2(\mathrm{c}, \mathrm{d}, \mathrm{e})$ & $2(\mathrm{f}, \mathrm{g}, \mathrm{h})$ & 3 & 4 & \\
\hline 4 & Nur Oktaviani & $1(\mathrm{a}, \mathrm{b})$ & $1(\mathrm{c}, \mathrm{d})$ & $2(a, b)$ & $2(\mathrm{c}, \mathrm{d}, \mathrm{e})$ & $2(\mathrm{f}, \mathrm{g}, \mathrm{h})$ & 3 & 4 & \\
\hline 5 & Hisdar & $1(a, b)$ & $1(\mathrm{c}, \mathrm{d})$ & $2(a, b)$ & $2(\mathrm{c}, \mathrm{d}, \mathrm{e})$ & $2(\mathrm{f}, \mathrm{g}, \mathrm{h})$ & 3 & 4 & \\
\hline 6 & Indra Purnama Jaya & $1(\mathrm{a}, \mathrm{b})$ & $1(\mathrm{c}, \mathrm{d})$ & $2(a, b)$ & $2(\mathrm{c}, \mathrm{d}, \mathrm{e})$ & $2(\mathrm{f}, \mathrm{g}, \mathrm{h})$ & 3 & 4 & \\
\hline
\end{tabular}

Tabel 4.4: Lembar observasi aktivitas mahasiswa terkait strategi pemecahan masalah Polya pada mata kuliah geometri semester IIC

\begin{tabular}{|c|c|c|c|c|c|c|c|c|c|}
\hline \multirow[b]{2}{*}{ No } & \multirow[b]{2}{*}{ Nama Mahasiwa } & \multicolumn{7}{|c|}{ Aktivitas Mahasiswa Menit Ke- } & \multirow[b]{2}{*}{ Ket. } \\
\hline & & 5 & 10 & 15 & 20 & 25 & 30 & 35 & \\
\hline 1 & Sudarmin & $1(a, b)$ & $1(\mathrm{c}, \mathrm{d})$ & $2(\mathrm{a}, \mathrm{b}, \mathrm{c})$ & $2(d, e, f)$ & $2(\mathrm{~g}, \mathrm{~h})$ & 3 & 4 & \\
\hline 2 & Muh.Hanafi & $1(a, b)$ & $1(\mathrm{c}, \mathrm{d})$ & $2(a, b, c)$ & $2(\mathrm{~d}, \mathrm{e}, \mathrm{f})$ & $2(\mathrm{~g}, \mathrm{~h})$ & 3 & 4 & \\
\hline 3 & Sahariana & $1(a, b)$ & $1(\mathrm{c}, \mathrm{d})$ & $2(a, b, c)$ & $2(\mathrm{~d}, \mathrm{e}, \mathrm{f})$ & $2(\mathrm{~g}, \mathrm{~h})$ & 3 & 4 & \\
\hline 4 & Muh.Said Bahru & $1(a, b)$ & $1(\mathrm{c}, \mathrm{d})$ & $2(a, b, c)$ & $2(\mathrm{~d}, \mathrm{e}, \mathrm{f})$ & $2(\mathrm{~g}, \mathrm{~h})$ & 3 & 4 & \\
\hline 5 & Ummi Kalsum & $1(a, b)$ & $1(\mathrm{c}, \mathrm{d})$ & $2(\mathrm{a}, \mathrm{b}, \mathrm{c})$ & $2(\mathrm{~d}, \mathrm{e}, \mathrm{f})$ & $2(\mathrm{~g}, \mathrm{~h})$ & 3 & 4 & \\
\hline 6 & Sugiarti & $1(a, b)$ & $1(\mathrm{c}, \mathrm{d})$ & $2(a, b, c)$ & $2(d, e, f)$ & $2(\mathrm{~g}, \mathrm{~h})$ & 3 & 4 & \\
\hline
\end{tabular}


71 | al-Khwarizmi, Volume III, Edisi 1, Maret 2015, Hal. 63 - 82.

c. Analisis deskriptif respon mahasiswa

Hasil analisis deskriptif respon mahasiswa terkait strategi pemecahan masalah Polya yang diberikan digambarkan pada tabel di bawah ini:

Tabel 4.8: Angket respon mahasiswa semester IIA

\begin{tabular}{|c|c|c|c|c|c|c|}
\hline No & Pernyataan & SS & $\mathbf{S}$ & $\mathbf{R}$ & TS & STS \\
\hline \multirow[t]{5}{*}{1} & See (memahami masalah) & & & & & \\
\hline & $\begin{array}{l}\text { a. Dosen memberikan masalah yang terkait dengan konsep luas } \\
\text { segitiga \& segiempat. }\end{array}$ & 1 & 5 & 0 & 0 & 0 \\
\hline & $\begin{array}{l}\text { b. Dosen memberikan masalah yang tidak berkaitan dengan konsep } \\
\text { luas segitiga dan segiempat. }\end{array}$ & 1 & 1 & 1 & 2 & 1 \\
\hline & $\begin{array}{l}\text { c. Dosen mengidetifikasi masalah-masalah terkait dengan konsep } \\
\text { luas segitiga \& segiempat. }\end{array}$ & 1 & 4 & 0 & 1 & 0 \\
\hline & $\begin{array}{l}\text { d. Dosen tidak mengidetifikasi masalah-masalah terkait dengan } \\
\text { konsep luas segitiga \& segiempat. }\end{array}$ & 0 & 0 & 0 & 5 & 1 \\
\hline \multirow[t]{16}{*}{2} & Plan (menyusun rencana) & & & & & \\
\hline & $\begin{array}{l}\text { b. Dosen membuat rencana pemecahan masalah yang sistematis } \\
\text { terkait dengan konsep luas segitiga \& segiempat. }\end{array}$ & 0 & 6 & 0 & 0 & 0 \\
\hline & $\begin{array}{l}\text { c. Dosen mengarahkan mahasiswa untuk mengaitkan masalah } \\
\text { yang tidak diketahui dengan yang diketahui terkait dengan } \\
\text { konsep luas segitiga \& segiempat. }\end{array}$ & 0 & 6 & 0 & 0 & 0 \\
\hline & $\begin{array}{l}\text { Dosen tidak mengarahkan mahasiswa untuk mengaitkan } \\
\text { masalah yang tidak diketahui dengan yang diketahui terkait } \\
\text { dengan konsep luas segitiga \& segiempat. }\end{array}$ & 0 & 0 & 2 & 4 & 0 \\
\hline & Dosen mengarahkan untuk membuat sub-sub masalah & 0 & 4 & 0 & 2 & 0 \\
\hline & Dosen mengarahkan untuk mengenali suatu masalah & 0 & 6 & 0 & 0 & 0 \\
\hline & $\begin{array}{l}\text { g. Dosen tidak mengarahkan untuk membuat sub-sub masalah dan } \\
\text { mengenalinya. }\end{array}$ & 0 & 0 & 2 & 4 & 0 \\
\hline & h. Dosen mengarahkan untuk membuat polanya. & 0 & 6 & 0 & 0 & 0 \\
\hline & Dosen tidak mengarahkan untuk membuat polanya. & 0 & 0 & 2 & 4 & 0 \\
\hline & $\begin{array}{l}\text { j. Dosen mengarahkan untuk menggunakan analogi dari masalah } \\
\text { konsep luas segitiga \& segiempat. }\end{array}$ & 1 & 4 & 1 & 0 & 0 \\
\hline & $\begin{array}{l}\text { k. Dosen mengarahkan untuk membuat analogi dari masalah yang } \\
\text { bukan konsep luas segitiga \& segiempat. }\end{array}$ & 1 & 4 & 0 & 1 & 0 \\
\hline & $\begin{array}{l}\text { 1. Dosen mengarahkan untuk membuat sesuatu yang baru, dengan } \\
\text { membuat hubungan antara data dengan yang diketahui. }\end{array}$ & 0 & 6 & 0 & 0 & 0 \\
\hline & m. Dosen mengarahkan untuk membuat kasus & 0 & 5 & 0 & 1 & 0 \\
\hline & n. Dosen tidak mengarahkan untuk membuat kasus & 0 & 2 & 0 & 4 & 0 \\
\hline & $\begin{array}{lllll}\text { o. } & \begin{array}{l}\text { Dosen mengarahkan untuk memulai dari akhir untuk } \\
\text { mengasumsikan jawabannya. }\end{array}\end{array}$ & 5 & 0 & 1 & 0 & 0 \\
\hline & p. Dosen mengarahkan untuk menyimpulkan jawabannya & 3 & 3 & 0 & 0 & 0 \\
\hline \multirow[t]{3}{*}{3} & Do (melaksanakan rencana) & & & & & \\
\hline & $\begin{array}{l}\text { a. } \begin{array}{l}\text { Dosen mengarahkan untuk melaksanakan rencana penyelesaian } \\
\text { masalah terkait dengan konsep luas segitiga \& segiempat. }\end{array} \\
\text { a sal }\end{array}$ & 2 & 3 & 1 & 0 & 0 \\
\hline & $\begin{array}{l}\text { b. Dosen mengarahkan untuk melaksanakan rencana penyelesaian } \\
\text { masalah yang bukan berkaitan dengan konsep luas segitiga \& } \\
\text { segiempat. }\end{array}$ & 1 & 3 & 1 & 1 & 0 \\
\hline \multirow[t]{5}{*}{4} & Check (menguji kembali) & & & & & \\
\hline & a. Dosen mengarahkan untuk menguji solusi yang didapatkan & 1 & 4 & 0 & 1 & 0 \\
\hline & b. Dosen tidak mengarahkan untuk menguji solusi yang didapatkan & 0 & 1 & 0 & 4 & 1 \\
\hline & c. Dosen mengarahkan untuk mengkritisi hasil yang didapatkan & 0 & 6 & 0 & 0 & 0 \\
\hline & $\begin{array}{llllll}\text { d. } & \begin{array}{l}\text { Dosen tidak mengarahkan untuk mengkritisi hasil yang } \\
\text { didapatkan }\end{array}\end{array}$ & 0 & 1 & 0 & 5 & 0 \\
\hline
\end{tabular}


Strategi Pembelajaran untuk ... 72

\begin{tabular}{|l|c|c|c|c|c|c|}
\hline & e. $\begin{array}{l}\text { Dosen menekankan bahwa penggunaan objek yang dicontohkan } \\
\text { dapat diganti dengan satu model yang lebih sederhana. }\end{array}$ & 2 & 4 & 0 & 0 & 0 \\
\hline & f. $\begin{array}{l}\text { Dosen tidak menekankan penggunaan objek untuk diganti } \\
\text { dengan satu model yang lebih sederhana. }\end{array}$ & 0 & 1 & 0 & 4 & 1 \\
\hline
\end{tabular}

Tabel 4.9: Angket respon mahasiswa semester IIB

\begin{tabular}{|c|c|c|c|c|c|c|}
\hline NO & PERNYATAAN & SS & $\mathbf{S}$ & $\mathbf{R}$ & TS & STS \\
\hline \multirow[t]{5}{*}{1} & See (memahami masalah) & & & & & \\
\hline & $\begin{array}{l}\text { a. Dosen memberikan masalah yang terkait dengan konsep luas } \\
\text { segitiga \& segiempat. }\end{array}$ & 4 & 2 & 0 & 0 & 0 \\
\hline & $\begin{array}{l}\text { b. Dosen memberikan masalah yang tidak berkaitan dengan } \\
\text { konsep luas segitiga dan segiempat. }\end{array}$ & 0 & 0 & 1 & 2 & 3 \\
\hline & $\begin{array}{l}\text { c. Dosen mengidetifikasi masalah-masalah terkait dengan konsep } \\
\text { luas segitiga \& segiempat. }\end{array}$ & 5 & 1 & 0 & 0 & 0 \\
\hline & $\begin{array}{l}\text { d. Dosen tidak mengidetifikasi masalah-masalah terkait dengan } \\
\text { konsep luas segitiga \& segiempat. }\end{array}$ & 0 & 0 & 0 & 3 & 3 \\
\hline \multirow[t]{16}{*}{2} & Plan (menyusun rencana) & & & & & \\
\hline & $\begin{array}{l}\text { a. Dosen membuat rencana pemecahan masalah yang sistematis } \\
\text { terkait dengan konsep luas segitiga \& segiempat. }\end{array}$ & 2 & 4 & 0 & 0 & 0 \\
\hline & $\begin{array}{l}\text { b. Dosen mengarahkan mahasiswa untuk mengaitkan masalah } \\
\text { yang tidak diketahui dengan yang diketahui terkait dengan } \\
\text { konsep luas segitiga \& segiempat. }\end{array}$ & 2 & 4 & 0 & 0 & 0 \\
\hline & $\begin{array}{l}\text { c. Dosen tidak mengarahkan mahasiswa untuk mengaitkan } \\
\text { masalah yang tidak diketahui dengan yang diketahui terkait } \\
\text { dengan konsep luas segitiga \& segiempat. }\end{array}$ & 0 & 0 & 2 & 4 & 0 \\
\hline & d. Dosen mengarahkan untuk membuat sub-sub masalah & 0 & 6 & 0 & 0 & 0 \\
\hline & e. Dosen mengarahkan untuk mengenali suatu masalah & 2 & 4 & 0 & 0 & 0 \\
\hline & $\begin{array}{l}\text { f. Dosen tidak mengarahkan untuk membuat sub-sub masalah } \\
\text { dan mengenalinya. }\end{array}$ & 0 & 0 & 2 & 4 & 0 \\
\hline & g. Dosen mengarahkan untuk membuat polanya. & 0 & 6 & 0 & 0 & 0 \\
\hline & h. Dosen tidak mengarahkan untuk membuat polanya. & 0 & 0 & 0 & 6 & 0 \\
\hline & $\begin{array}{l}\text { i. Dosen mengarahkan untuk menggunakan analogi dari } \\
\text { masalah konsep luas segitiga \& segiempat. }\end{array}$ & 1 & 3 & 2 & 0 & 0 \\
\hline & $\begin{array}{l}\text { j. Dosen mengarahkan untuk membuat analogi dari masalah } \\
\text { yang bukan konsep luas segitiga \& segiempat. }\end{array}$ & 0 & 2 & 1 & 1 & 2 \\
\hline & $\begin{array}{l}\text { k. Dosen mengarahkan untuk membuat sesuatu yang baru, } \\
\text { dengan membuat hubungan antara data dengan yang } \\
\text { diketahui. }\end{array}$ & 0 & 6 & 0 & 0 & 0 \\
\hline & 1. Dosen mengarahkan untuk membuat kasus & 0 & 6 & 0 & 0 & 0 \\
\hline & m. Dosen tidak mengarahkan untuk membuat kasus & 0 & 1 & 3 & 1 & 1 \\
\hline & $\begin{array}{llllll}\text { n. } & \begin{array}{l}\text { Dosen mengarahkan untuk memulai dari akhir untuk } \\
\text { mengasumsikan jawabannya. }\end{array} & & & \\
\end{array}$ & 3 & 3 & 0 & 0 & 0 \\
\hline & o. Dosen mengarahkan untuk menyimpulkan jawabannya & 3 & 3 & 0 & 0 & 0 \\
\hline \multirow[t]{3}{*}{3} & Do (melaksanakan rencana) & & & & & \\
\hline & $\begin{array}{lll}\text { a. } & \begin{array}{l}\text { Dosen mengarahkan untuk melaksanakan rencana } \\
\text { penyelesaian masalah terkait dengan konsep luas segitiga \& } \\
\text { segiempat. }\end{array} \\
\end{array}$ & 0 & 6 & 0 & 0 & 0 \\
\hline & $\begin{array}{l}\text { b. Dosen mengarahkan untuk melaksanakan rencana } \\
\text { penyelesaian masalah yang bukan berkaitan dengan konsep } \\
\text { luas segitiga \& segiempat. }\end{array}$ & 0 & 0 & 1 & 4 & 1 \\
\hline \multirow[t]{4}{*}{4} & Check (menguji kembali) & & & & & \\
\hline & a. $\quad$ Dosen mengarahkan untuk menguji solusi yang didapatkan & 2 & 4 & 0 & 0 & 0 \\
\hline & $\begin{array}{l}\text { b. Dosen tidak mengarahkan untuk menguji solusi yang } \\
\text { didapatkan }\end{array}$ & 0 & 1 & 1 & 3 & 1 \\
\hline & c. Dosen mengarahkan untuk mengkritisi hasil yang didapatkan & 2 & 4 & 0 & 0 & 0 \\
\hline
\end{tabular}


73 al-Khwarizmi, Volume III, Edisi 1, Maret 2015, Hal. 63 - 82.

\begin{tabular}{|l|l|l|l|l|l|l|}
\hline & d. $\begin{array}{l}\text { Dosen tidak mengarahkan untuk mengkritisi hasil yang } \\
\text { didapatkan }\end{array}$ & 0 & 0 & 2 & 2 & 2 \\
\hline e. $\begin{array}{l}\text { Dosen menekankan bahwa penggunaan objek yang } \\
\text { dicontohkan dapat diganti dengan satu model yang lebih } \\
\text { sederhana. }\end{array}$ & 2 & 4 & 0 & 0 & 0 \\
\hline f. $\begin{array}{l}\text { Dosen tidak menekankan penggunaan objek untuk diganti } \\
\text { dengan satu model yang lebih sederhana. }\end{array}$ & 0 & 0 & 2 & 3 \\
\hline
\end{tabular}

\section{Tabel 4.10: Angket respon mahasiswa semester IIC}

\begin{tabular}{|c|c|c|c|c|c|c|}
\hline NO & PERNYATAAN & SS & $\mathbf{S}$ & $\mathbf{R}$ & TS & STS \\
\hline \multirow[t]{5}{*}{1} & See (memahami masalah) & & & & & \\
\hline & $\begin{array}{l}\text { a. Dosen memberikan masalah yang terkait dengan konsep luas } \\
\text { segitiga \& segiempat. }\end{array}$ & 1 & 5 & 0 & 0 & 0 \\
\hline & $\begin{array}{l}\text { b. Dosen memberikan masalah yang tidak berkaitan dengan } \\
\text { konsep luas segitiga dan segiempat. }\end{array}$ & 1 & 0 & 0 & 4 & 1 \\
\hline & $\begin{array}{l}\text { c. Dosen mengidetifikasi masalah-masalah terkait dengan konsep } \\
\text { luas segitiga \& segiempat. }\end{array}$ & 1 & 4 & 1 & 0 & 0 \\
\hline & $\begin{array}{l}\text { d. Dosen tidak mengidetifikasi masalah-masalah terkait dengan } \\
\text { konsep luas segitiga \& segiempat. }\end{array}$ & 0 & 0 & 1 & 3 & 2 \\
\hline \multirow[t]{16}{*}{2} & Plan (menyusun rencana) & & & & & \\
\hline & $\begin{array}{l}\text { a. Dosen membuat rencana pemecahan masalah yang sistematis } \\
\text { terkait dengan konsep luas segitiga \& segiempat. }\end{array}$ & 0 & 6 & 0 & 0 & 0 \\
\hline & $\begin{array}{l}\text { b. Dosen mengarahkan mahasiswa untuk mengaitkan masalah } \\
\text { yang tidak diketahui dengan yang diketahui terkait dengan } \\
\text { konsep luas segitiga \& segiempat. }\end{array}$ & 0 & 6 & 0 & 0 & 0 \\
\hline & $\begin{array}{l}\text { c. Dosen tidak mengarahkan mahasiswa untuk mengaitkan } \\
\text { masalah yang tidak diketahui dengan yang diketahui terkait } \\
\text { dengan konsep luas segitiga \& segiempat. }\end{array}$ & 0 & 0 & 1 & 2 & 3 \\
\hline & d. Dosen mengarahkan untuk membuat sub-sub masalah & 1 & 3 & 2 & 0 & 0 \\
\hline & e. Dosen mengarahkan untuk mengenali suatu masalah & 1 & 4 & 1 & 0 & 0 \\
\hline & $\begin{array}{ll}\text { f. } & \text { Dosen tidak mengarahkan untuk membuat sub-sub masalah } \\
\text { dan mengenalinya. }\end{array}$ & 0 & 0 & 1 & 2 & 3 \\
\hline & g. Dosen mengarahkan untuk membuat polanya. & 2 & 4 & & & \\
\hline & h. Dosen tidak mengarahkan untuk membuat polanya. & 0 & 1 & 1 & 2 & 2 \\
\hline & $\begin{array}{l}\text { i. Dosen mengarahkan untuk menggunakan analogi dari masalah } \\
\text { konsep luas segitiga \& segiempat. }\end{array}$ & 2 & 3 & 0 & 1 & 0 \\
\hline & $\begin{array}{l}\text { j. Dosen mengarahkan untuk membuat analogi dari masalah } \\
\text { yang bukan konsep luas segitiga \& segiempat. }\end{array}$ & 1 & 4 & 0 & 1 & 0 \\
\hline & $\begin{array}{l}\text { k. Dosen mengarahkan untuk membuat sesuatu yang baru, } \\
\text { dengan membuat hubungan antara data dengan yang } \\
\text { diketahui. }\end{array}$ & 0 & 6 & 0 & 0 & 0 \\
\hline & 1. $\quad$ Dosen mengarahkan untuk membuat kasus & 1 & 4 & 1 & 0 & 0 \\
\hline & m. Dosen tidak mengarahkan untuk membuat kasus & 0 & 0 & 2 & 4 & 0 \\
\hline & $\begin{array}{llllll}\text { n. } & \begin{array}{l}\text { Dosen mengarahkan untuk memulai dari akhir untuk } \\
\text { mengasumsikan jawabannya. }\end{array}\end{array}$ & 4 & 2 & 0 & 0 & 0 \\
\hline & o. Dosen mengarahkan untuk menyimpulkan jawabannya & 5 & 1 & 0 & 0 & 0 \\
\hline \multirow[t]{3}{*}{3} & Do (melaksanakan rencana) & & & & & \\
\hline & $\begin{array}{l}\text { a. Dosen mengarahkan untuk melaksanakan rencana penyelesaian } \\
\text { masalah terkait dengan konsep luas segitiga \& segiempat. }\end{array}$ & 0 & 6 & 0 & 0 & 0 \\
\hline & $\begin{array}{lll}\text { b. } & \text { Dosen mengarahkan untuk melaksanakan rencana } \\
\text { penyelesaian masalah yang bukan berkaitan dengan konsep } \\
\text { luas segitiga \& segiempat. }\end{array}$ & 0 & 2 & 1 & 3 & 0 \\
\hline \multirow[t]{3}{*}{4} & Check (menguji kembali) & & & & & \\
\hline & a. Dosen mengarahkan untuk menguji solusi yang didapatkan & 2 & 4 & 0 & 0 & 0 \\
\hline & b. Dosen tidak mengarahkan untuk menguji solusi yang & 0 & 0 & 1 & 5 & 0 \\
\hline
\end{tabular}


Strategi Pembelajaran untuk ...| $\mathbf{7 4}$

\begin{tabular}{|c|c|c|c|c|c|c|}
\hline & didapatkan & & & & & \\
\hline & c. Dosen mengarahkan untuk mengkritisi hasil yang didapatkan & 1 & 5 & 0 & 0 & 0 \\
\hline & $\begin{array}{ll}\text { d. Dosen tidak mengarahkan untuk mengkritisi hasil yang } \\
\text { didapatkan }\end{array}$ & 0 & 0 & 2 & 4 & 0 \\
\hline & $\begin{array}{ll}\text { e. Dosen menekankan bahwa penggunaan objek yang } \\
\text { dicontohkan dapat diganti dengan satu model yang lebih } \\
\text { sederhana. }\end{array}$ & 0 & 6 & 0 & 0 & 0 \\
\hline & $\begin{array}{l}\text { f. Dosen tidak menekankan penggunaan objek untuk diganti } \\
\text { dengan satu model yang lebih sederhana. }\end{array}$ & 0 & 1 & 1 & 4 & 0 \\
\hline
\end{tabular}

\section{B. Pembahasan}

1. Strategi pembelajaran pemecahan masalah Polya

Gambaran strategi pembelajaran terkait kemampuan pemecahan masalah Polya bagi mahasiswa yang mengalami problema belajar adalah sebagai berikut:

Gambaran umum kerangka kerja Polya adalah sebagai berikut:

a) Pemahaman pada masalah (identifikasi dari tujuan)

b) Membuat rencana pemecahan masalah

c) Melaksanakan Rencana

d) Lihatlah kembali

Berdasarkan kerangka kerja Polya di atas, kemampuan mahasiswa dalam menyelesaikan masalah terkait dengan konsep luas segitiga dan segiempat pada dasarnya sudah bagus. Akan tetapi masih ada beberapa langkah yang belum sistematis. Pada saat observasi pertama dilakukan terlihat bahwa kemampuan mahasiswa dalam memahami masalah yang diberikan berbedabeda berdasarkan kerangka kerja Polya. Selanjutnya pada tahap membuat rencana pemecahan masalah kemampuan mahasiswa juga berbeda berdasarkan tingkatan kerja dalam rencana pemecahan masalah yang diberikan. Pada pembelajaran berikutnya telah dikemukakan kepada mahasiswa bentuk kerangka kerja pemecahan masalah Polya sehingga ketika diberikan masalah terkait dengan konsep luas segitiga dan segiempat, kemampuan mahasiswa dalam memecahkan masalah berangsur-angsur lebih sistematis berdasarkan kerangka kerja yang telah diberikan. Hal ini dimaksudkan untuk mengarahkan mahasiswa yang mengalami problema belajar bahwa memecahkan masalah harus dengan langkah-langkah yang sistematis.Demikian halnya dengan desain didaktis teori belajar Polya adalah sebagai berikut:

\section{A. Identitas Matakuliah \\ 1. Nama Matakuliah \\ 2. Kode Matakuliah \\ 3. Jumlah SKS \\ 4. Jenjang}

\section{SILABUS}

Geometri

MKK12603

2 (Dua) SKS

Strata Satu (S1) 
75 | al-Khwarizmi, Volume III, Edisi 1, Maret 2015, Hal. 63 - 82.
5. Semester
I (Empat)
6. Jumlah Pertemuan
14 (Empat Belas) Kali Pertemuan
7. Dosen Matakuliah
Andi Ika Prasasti Abrar, S.Si., M.Pd.

B. Deskripsi Matakuliah

Secara umum materi perkuliahan terdiri atas dua bagian, yaitu Geometri Bidang dan Geometri Ruang. Dalam Geometri Bidang akan dipelajari mengenai pengertian garis, sudut, ukuran sudut, kesejajaran dan ketegaklurusan dua garis, segitiga, segiempat, kekongruenan dan kesebangunan dua bangun, luas daerah bangun, teorema Pythagoras, segi-banyak, lingkaran, dan sistem koordinat. Sedangkan dalam Geometri Ruang akan dipelajari mengenai gambar proyeksi miring suatu bangun ruang, relasi antarunsur-unsur ruang, kesejajaran dan ketegaklurusan dalam ruang, proyeksi, jarak, dan sudut dalam ruang, serta berbagai karakteristik dan luas maupun volum bangunbangun ruang, seperti kubus, balok, limas, tabung, kerucut, dan bola.

C. Tujuan

Mahasiswa diharapkan dapat menjelaskan berbagai konsep-konsep geometri sebagai sistem deduktif, memiliki daya tanggap ruang yang tajam, dan mampu menjelaskan karakteristik berbagai bangun geometri.

D. Pendekatan

Metode

Tugas

Media

: Ceramah, tanya jawab, diskusi, dan pemecahan masalah

: Latihan soal, penyajian, dan diskusi.

: Whiteboard, LCD.

E. Rubrik Penilaian

1. Absensi

2. Tugasn (Mandiri dan atau Kelompok)

3. Ujian Tengah Semester (UTS)

4. Ujian Akhir Semester (UAS)

F. Rincian Pokok Bahasan dan Rencana Alokasi Waktu

\begin{tabular}{|c|c|c|}
\hline No & Pokok Bahasan dan Sub Pokok Bahasan & $\begin{array}{l}\text { Pertemuan } \\
\text { Ke- }\end{array}$ \\
\hline \multicolumn{2}{|c|}{ Perkenalan \& Kontrak Perkuliahan } & 1 \\
\hline 1 & Dasar-Dasar Geometri & \\
\hline & 1.1. Titik, Garis, Bidang, dang Ruang & \multirow{3}{*}{2} \\
\hline & 1.2. Sinar garis, Ruas Garis, dan Sudut & \\
\hline & 1.3. Kurva dan Jenis-Jenis Kurva & \\
\hline \multirow[t]{4}{*}{2} & Segi Banyak & \\
\hline & 2.1. Segitiga & \multirow{3}{*}{3} \\
\hline & 2.2. Segi Empat dan Segi Lima & \\
\hline & 2.3. Kongruensi dan Kesebangunan & \\
\hline \multirow[t]{4}{*}{3} & Simetri & \\
\hline & 3.1. Refleksi & \multirow{3}{*}{4} \\
\hline & 3.2. Rotasi & \\
\hline & 3.3. Simetri & \\
\hline \multirow[t]{4}{*}{4} & Persamaan Garis & \\
\hline & 4.1. Gradien Garis & \multirow{3}{*}{$5 \& 6$} \\
\hline & 4.2. Persamaan Garis & \\
\hline & $\begin{array}{l}\text { 4.3. Persamaan Garis Sejajar dan Tegak Lurus Garis } \\
\text { Lain }\end{array}$ & \\
\hline \multicolumn{2}{|c|}{ Ujian Tengah Semester (UTS) } & 7 \\
\hline 5 & Bangun Ruang & 8 \\
\hline \multirow[t]{4}{*}{6} & Jaring-Jaring Bangun Ruang & \\
\hline & 6.1. Bangun Ruang Permukaan Lengkung & \multirow{3}{*}{9} \\
\hline & 6.2. Jaring-Jaring Bidang Empat dan Bidang Enam & \\
\hline & 6.3. Jaring-Jaring Silinder dan Kerucut & \\
\hline \multirow[t]{2}{*}{7} & Satuan Ukur dan Keliling & \\
\hline & $\begin{array}{l}\text { 7.1. Satuan Ukur, Keliling Kurva, dan Keliling } \\
\text { Segitiga }\end{array}$ & 10 \\
\hline
\end{tabular}


Strategi Pembelajaran untuk ...| 76

\begin{tabular}{|l|l|c|}
\hline & 7.2. Keliling Segiempat dan Keliling Lingkaran & \\
\cline { 2 - 3 } & Luas Daerah & \multirow{2}{*}{11} \\
\cline { 2 - 3 } & $\begin{array}{l}\text { 8.1. Pengubinan, Rangkaian Bidang Datar } \\
\text { 8.2. Luas Segitiga dan Luas Segi Empat }\end{array}$ & \multirow{2}{*}{12 \& 13} \\
\hline 9 & $\begin{array}{l}\text { Volume Bangun Ruang dan Berat } \\
\text { 9.1. Konsep Volume, Volume Kubus, Balok }\end{array}$ & $\begin{array}{l}\text { 9.2. Volumen Bangun Ruang (Bersisi Datar dan } \\
\text { Lengkung) }\end{array}$ \\
\hline
\end{tabular}

G. Referensi

[1].Anglin, W. S. Mathematics: A Concise History and Philosophy. New York: Springer-Verlag New York, Inc.

[2]Bob Underhill, 1981. Teaching Elementary School Mathematics. Charles

E Merril Publishing Company: Toronto.

[3].Clemens Stanley, 1994. Geometry. Publishing Addison; Canada.

[4]. Kenneth Travers, 1987. Geometry. Laidlaw Brother: Illionis.

[5]. Ruseffendi, H. E. T. (189). Dasar-Dasar Matematika Modern dan Komputer untuk Guru.Bandung: Tarsito.

Palopo,

Dosen Matakuliah

\section{SATUAN ACARA PERKULIAHAN}

$\begin{array}{ll}\text { Mata Kuliah } & : \text { Geometri } \\ \text { Jumlah SKS } & : 2 \text { (Dua) SKS } \\ \text { Pokok Bahasan } & : \text { Satuan Ukur dan Keliling } \\ \text { Pertemuan } & : 10\end{array}$

\section{Kompetensi Dasar}

Mahasiswa mampu memahami konsep satuan ukur, keliling kurva dan keliling segitiga denganbaik untuk kemudian diaplikasikan dalam penyelesaian masalah.

\section{Indikator}

Mahasiswa diharapkan mampu:

1. Memahami pengertian satuan ukur, keliling kurva, dan keliling segitiga

2. Mengaplikasikan konsep kelliling kurva dan keliling segitiga dalam penyelesaian masalah

\section{Ringkasan Materi}

\section{SATUAN UKUR DAN KELILING}

1. Satuan Ukur, Keliling Segiempat, dan Keliling Lingkaran

Pengukuran adalah suatu proses memberikan bilangan kepada kualitas fisik panjang, kapasitas, volume, luas, sudut, berat (massa), dan suhu (kennedy dan Tips, 1994). Satuan ukuran yang akan kita bahas adalah berupa panjang, berat.

Jenis-jenis pengukuran ada 2 yaitu pengukurn atidak baku dan pengukuran baku.

a. Pengukuran baku

Pengukuran baku merupakan pengukuran yang hasilnya tetap atau baku (Standar).Terdapat dua sistem pengukuran yang baku.yaitu pengukuran sistem Inggris dan Sistem Metrik. Ukuran dalam sistem Inggris misalnya 12 inchi $=1$ kaki. Sementara ukuran metrik misalnya $10 \mathrm{~mm}=1 \mathrm{~cm}$.

b. Pengukuran tidak baku

Pengukuran tidak baku merupakan pengukuran yang hasilnya berbeda-beda karena menggunakan alat ukur yang tidak baku atau tidak standar. Pengukuran tidak baku misalnya jenkal, hasta, depa, dsb.

2. Keliling Segiempat dan Keliling Lingkaran a. Persegi Panjang 


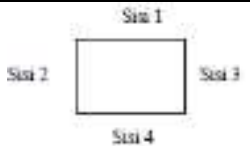

Sifat dari persegi panjang memiliki 4 sisi yang saling tegak lurus.panjang, memiliki sisi yang berhadapan sama panjang dan sejajar. Sehingga Sisi $1=\operatorname{sisi} 4$ dan sisi $2=$ sisi 3. Konsep keliling dapat kita terapkan yaitu sisi $1+\operatorname{sisi} 2+\operatorname{sisi} 3+\operatorname{sisi} 4$. Jika Sisi $1=$ sisi 4 adalah $\mathrm{p}$ (panjang) dan sisi $2=$ sisi $3=1$ (lebar) maka keliling persegipanjang dapat kita tentukan

b. Persegi

$$
\mathrm{K}=(\mathrm{p}+\mathrm{p})+(1+1)=2 \mathrm{p}+2 \mathrm{l}=2(\mathrm{p}+1)
$$

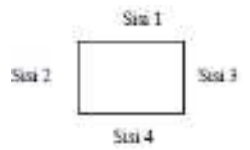

Sifat dari persegi adalah memiliki empat sisi yang sama panjang.Sehingga keliling dari persegi adalah jumlah dari keempat sisinya atau sisi $1+\operatorname{sisi} 2+\operatorname{sisi} 3+$ sisi 4 . Jika sisi $1=$ sisi $2=s i s i 3=s i s i 4=s$ maka Keliling persegi dapat dirumuskan sebagai berikut:

c. Jajar Genjang

$$
\mathrm{K}=\mathrm{s}+\mathrm{s}+\mathrm{s}+\mathrm{s}=4 \mathrm{~s}
$$

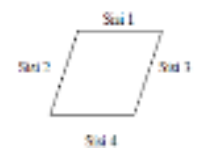

Sifat Jajar genjang memiliki 4 sisi yang terdiri dari sisi 1 yang sejajar dengan sisi 4 dan sisi 2 yang sejajar dengan sisi 3.Keliling Jajaegenjang dapat dengan mudah kita tentukan dengan menjumlahkan $=$ sisi $1+\operatorname{sisi} 2+\operatorname{sisi} 3+\operatorname{sisi} 4$. Jika kita tentukan bahwa sisi $1=\operatorname{sisi} 4=\mathrm{a}$ dan $\operatorname{sisi} 2=\operatorname{sisi} 3=\mathrm{b}$ maka:

\section{d. Belah Ketupat}

$$
\mathrm{K}=(\mathrm{a}+\mathrm{a})+(\mathrm{b}+\mathrm{b})=2 \mathrm{a}+2 \mathrm{~b}=2(\mathrm{a}+\mathrm{b})
$$

Sifat dari belah ketupat memiliki 4 sisi yang sama panjang maka kita dapat menentukan keliling belahketupat dengan menjulhkan keempat sisi-sisinya. Keliling belah ketupat $=\operatorname{sisi} 1+\operatorname{sisi} 2+\operatorname{sisi} 3+\operatorname{sisi} 4$. Karena belah ketupat memiliki 4 sisi yang sama panjang, jika sisi $1=\operatorname{sisi} 2=\operatorname{sisi} 3$

$=\operatorname{sisi} 4=\mathrm{a}$, maka dapat kita simpulkan keliling belahketupat adalah

$$
\mathrm{K}=\mathrm{a}+\mathrm{a}+\mathrm{a}+\mathrm{a}=4 \mathrm{a}
$$

e. Layang-Layang

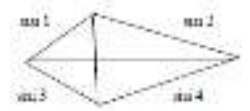

Sifat dari layang-layang adalah mempunyai sepasang-sepasang sisi yang sama panjang. Sehingga dapat kita tentukan bahwa sisi $1=$ sisi 3 dan sisi $2=$ sisi 4 . Keliling layang-layang dapat kita tentukan dengan menjumlahkan sisi $1+\operatorname{sisi} 2+\operatorname{sisi} 3+\operatorname{sisi} 4$. Jika sisi $1=\operatorname{sisi} 3=$ a dan sisi $2=\operatorname{sisi} 4=\mathrm{b}$. Rumus dari keliling layang-layang dapat kita tentukan sebagai berikut

$$
K=(a+a)+(b+b)=2 a+2 b=2(a+b)
$$




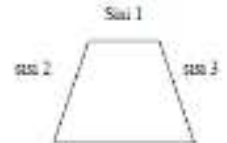

Sifat dari trapesium memiliki sepasang sisi yang berhadapan sejajar. Jika Anda perhatikan bahwa sisi $1^{1}$ sisi 4 dan sisi $2=$ sisi 3 . Namun keliling dari trapesium sama kaki dapat kita tentukan dengan menjumlahkan sisi $1+\operatorname{sisi} 2+$ sisi $3+$ sisi 4.Jika sisi 1 $=\mathrm{a}$, sisi $2=\operatorname{sisi} 3=\mathrm{b}$ dan sisi $4=\mathrm{c}$ maka dapat kita rumuskan

$$
\mathrm{K}=\mathrm{a}+\mathrm{b}+\mathrm{b}+\mathrm{c}=\mathrm{a}+2 \mathrm{~b}+\mathrm{c}
$$

g. Trapesium Sama Kaki

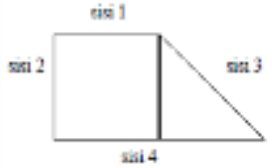

Keliling dapat anda tentukan dengan menjumlahkan sisi $1+\operatorname{sisi} 2+\operatorname{sisi} 3+$ sisi 4 . Jika Anda perhatikan sisi $1=\operatorname{sisi} 2$ dan sisi $3^{1}$ sisi 4 . Jika Anda memisalkan sisi $1=\operatorname{sisi} 2=$ $\mathrm{a}$, sisi $3=\mathrm{b}$ dan sisi $4=\mathrm{c}$ maka keliling trapesium dapat kita rumuskan:

$$
\mathrm{K}=\mathrm{a}+\mathrm{a}+\mathrm{b}+\mathrm{c}=2 \mathrm{a}+\mathrm{b}+\mathrm{c}
$$

h. Trapesium Sembarang

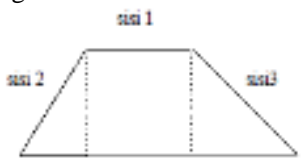

Keliling dapat Anda tentukan dengan menjumlahkan sisi $1+\operatorname{sisi} 2+\operatorname{sisi} 3+\operatorname{sisi} 4$, karena trapesium sebarang maka panjang setiap sisi tidak sama. Jika sisi $1=\mathrm{a}, \operatorname{sisi} 2=$ $\mathrm{b}$, sisi $3=\mathrm{c}$ dan sisi $4=\mathrm{d}$, maka keliling trapesium dapat kita rumuskan sebagai berikut:

i. Lingkaran

$$
\mathrm{K}=\mathrm{a}+\mathrm{b}+\mathrm{c}+\mathrm{d}
$$

Untuk menentukan konsep keliling lingkaran Anda dapat melakukan suatu percobaan dengan mengukur keliling atau panjang sisi lingkaran. Ketetapan $\mathrm{p}$ (phi) untuk suatu lingkaran adalah 3,14 atau 7/22, kemudian garis tengah atau garis terpanjang mempunyai hubungan dua kali jari-jari suatu lingkaran.

Rumus keliling lingkaran adalah:

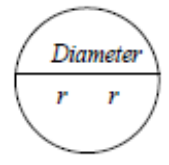

$$
\mathrm{K}=2 \pi \mathrm{r}
$$

\section{Evaluasi}

Memberikan soal-soal latihan yang diambil dan dikembangkan dari buku rujukan.

\section{SATUAN ACARA PERKULIAHAN}

$\begin{array}{ll}\text { Mata Kuliah } & : \text { Geometri } \\ \text { Jumlah SKS } & : 2 \text { (Dua) SKS } \\ \text { Pokok Bahasan } & : \text { Luas Daerah } \\ \text { Pertemuan } & : 11\end{array}$

\section{Kompetensi Dasar}

Mahasiswa mampu memahami konsep luas daerah dengan baik untuk kemudian diaplikasikan dalam penyelesaian masalah.

\section{Indikator}

Mahasiswa diharapkan mampu:

1. Mengetahui konsep pengubiman dan rangkaian bidang datar 
79 | al-Khwarizmi, Volume III, Edisi 1, Maret 2015, Hal. 63 - 82.

2. Mengetahui konsep luas suatu daerah

3. Memahami konsep luas daerah segitiga dan segi empat

III. Ringkasan Materi

LUAS DAERAH

1. Pengubinan dan Rangkaian Bidang Datar

Pemasangan atau penyusunan bangun datar dengan bangun-bangun datar lain (segibanyak) yang sisinya berimpit disebut pengubinan. Perhatikan contoh berikut:

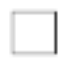

(a)

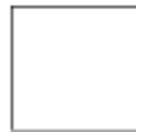

(b)

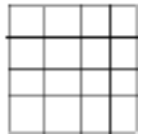

(c)

Gambar bagian (a) merupakan gambar pola berbentuk persegi, bagian (b) merupakan bangun datar yang akan ditutupi, dan (c) merupakan bangun datar hasil pengubinan.

2. Luas Segitiga dan Luas Segi Empat

a. Luas daerah persegi panjang

Untuk menjelaskan pemahaman luas persegi panjang kita kembali pada konsep perkalian. Kita ambil contoh 3 × $2=6$. Jika kita peragakan maka dapat kita gambarkan

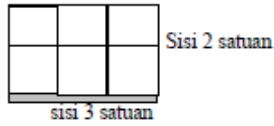

Sehingga dapat kita buat rumus luas Persegipanjang = sisi 3 satuan $\mathrm{x}$ sisi 2 satuan Jika sisi 3 satuan sebagai panjang dan sisi 2 satuan sebagai lebar. Maka luas persegi panjang adalah:

b. Luas daerah persegi

$$
\text { Luas }=\text { panjang } \mathrm{x} \text { lebar }
$$

Untuk menjelaskan pemahaman luas persegi kita kembali pada konsep perkalian. Kita ambil contoh $2 \times 2=4$. Jika kita peragakan maka dapat kita gambarkan

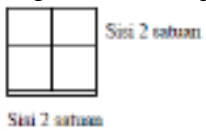

Dari peragaan diatas dapat kita buat konsep luas persegi $=$ sisi 2 satuan $\mathrm{x}$ sisi 2 satuan Jika kita nyatakan dengan sisi $\mathrm{x}$ sisi untuk semua persegi maka kita dapat menentukan rumus luas persegi sebagi berikut:

c. Luas daerah persegi

$$
\text { Luas }=\text { sisi } \mathrm{x} \text { sisi }
$$

Misalkan diambil satu persegi panjang dengan panjan $\mathrm{p}$ dan lebar $\mathrm{l}$ :

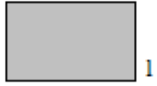

$\mathrm{p}$

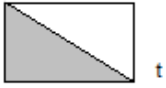

a

kemudian kita bagi dua dengan membagi daerah persegi panjang tersebut di diagonalnya. Kita lihat Daerah segitiga yang diarsir luasnya $=1 / 2$ dari luas persegi panjang. Jika kita buat dalam matematika formalnya yaitu:

Luas segitiga $=1 / 2 \times \mathrm{p} \times 1$,

karena $\mathrm{p}=$ alas dan $\mathrm{l}=$ tinggi sehingga luas segitiga menjadi:

Luas $=1 / 2 \times$ a $\times \mathrm{t}$

d. Luas daerah jajar genjang
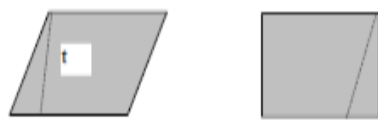

Jika kita bagi daerah jajargenjang tersebut dengan memotong garis putus-putus tersebut, kemudian kita tempatkan seperti pada gambar. Maka akan nampak sebuah bangun persegi panjang yang memiliki rumus luas $\mathrm{p} x$ l. Sehingga dengan asumsi $\mathrm{a}=\mathrm{p}$ dan $\mathrm{t}=1$ maka luas jajargenjang dapat kita rumuskan menjadi 
e. Luas daerah belah ketupat

Luas $=\mathrm{a} \times \mathrm{t}$

Jika dibagi, belah ketupat tersebut menjadi:

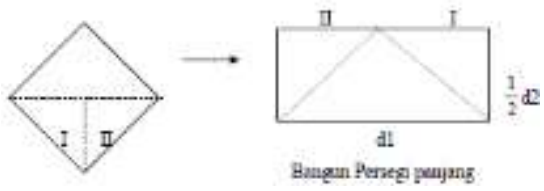

Belah ketupat yang telah kita bagi kemudian disusun menjadi bangun persegi panjang. Persegi panjang yang terbentuk mempunyai ukuran panjang d1 dan lebar $=1 / 2 \mathrm{~d} 2$. Sehingga Luas belah ketupat adalah:

$$
\text { Luas }=1 / 2 \times \mathrm{d} 1 \times \mathrm{d} 2
$$

f. Luas daerah palayng-layang
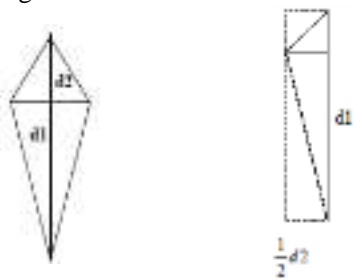

Layang-layang adalah segiempat yang mempunyai 2 pasang sisi sama panjang dan diagonalnya berpotongan saling tegak lurus. AC disebut diagonal $1=\mathrm{d} 1$ dan $\mathrm{BD}$ disebut diagonal $2=\mathrm{d} 2$. Dengan cara memotong diagonal AC maka bangun datar layang-layang dapat dibentuk menjadi

Layang-layang yang telah kita bagi kemudian disusun menjadi bangun persegi panjang.Persegi panjang yang terbentuk mempunyai ukuran panjang $=\mathrm{d} 1$ dan lebar $=$ $1 / 2 \mathrm{~d} 2$. Sehingga luas layang-layang adalah:

$$
\text { Luas }=1 / 2 \mathrm{~d} 1 \mathrm{xd} 2
$$

g. Luas daerah trapesium siku-siku

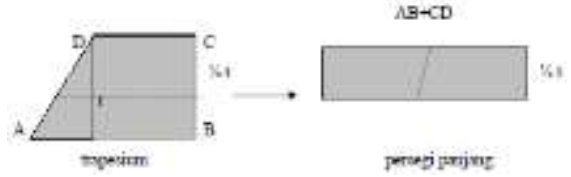

Terbentuk suatu persegi panjang dengan ukuran panjang $=A B+C D$ dan lebar $=1 / 2 \mathrm{t}$. Sehingga luas trapesium yang dimaksud adalah:

Luas $=$ luas persegi panjang $=$ panjang $\times$ lebar $=(A B+C D) \times 1 / 2 t$

Luas daerah trapesium samakaki

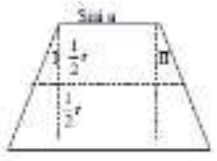

Sus b

Dengan cara Anda memindahkan segitiga I ke samping kiri bawah dan segitiga II ke samping kanan bawah. Maka Anda akan mendapatkan 2 persegi panjang, dengan luasnya yaitu a x $1 / 2 \mathrm{t}$ dan luas yang lainnya $b \times{ }^{1 / 2} \mathrm{t}$. Sehingga Anda akan mendapatkan total luas persegi panjang yang diperoleh dari bangun trapesium sama kaki adalah sama dengan luas trapesium = luas persegi panjang atas + luas persegi panjang yang bawah. 
h. luas daerah lingkaran

\section{Luas $=1 / 2 \mathrm{t}(\mathrm{a}+\mathrm{b})$}
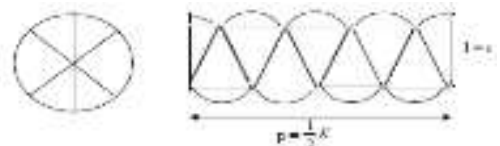

Setelah Anda memotong lingkaran menjadi bangun disamping ini, tampak hasilnya menyerupai bangun persegi panjang. Sehingga kita dapat menentukan konsep luas lingkaran dari konsep luas persegi panjang. Dengan panjang $=1 / 2$ keliling 1 ingkaran dan lebarnya $=r$, sehingga:

Luas lingkaran $=$ luas persegi panjang $=\pi r^{2}$

IV. Evaluasi

Memberikan soal-soal latihan yang diambil dan dikembangkan dari buku rujukan.

Berdasarkan desain tersebut memungkinkan dosen dalam mengarahkan mahasiswa yang mengalami problema belajar dapat menyelesaikan masalah yang diberikan sesaui dengan kerangka kerja yang telah ada. Setiap teori diberikan secara runut dengan konsep yang jelas. Respon mahasiswa terkait implementasi strategi pembelajaran yang diberikan pada dasarnya memberikan respon yang positif.

\section{Penutup}

A. Kesimpulan

1. Strategi pembelajaran bagi mahasiswa terkait kemampuan pemecahan masalah geometri mahasiswa semester II matematika STAIN Palopo mengacu pada kerangka kerja Polya

2. Desain didaktis teori belajar Polya untuk meningkatkan kemampuan pemecahan masalah geometri mahasiswa semester II matematika STAIN Palopo lebih ditekankan pada bentuk silabus dan SAP yang merincikan materi / bahan ajar yang runut.

3. Respon mahasiswa yang mengalami problema belajar terkait implementasi strategi pembelajaran yang diberikan adalah umumnya setuju terhadap strategi pembelajaran yang diberikan.

\section{B. Saran}

Berdasarkan hasil penelitian yang diperoleh pada mahasiswa semester II pendidikan matematika STAIN Palopo, maka dikemukakan saran-saran sebagai berikut:

1. Bagi para mahasiswa yang mengalami problema belajar agar dalam memecahkan masalah dapat menggunakan kerangka kerja Polya. 
2. Kepada para dosen yang mengajar selain mata kuliah geometri juga dapat mengaplikasikan konsep belajar Polya dalam pembelajarannya.

3. Bagi para peneliti berikutnya yang berminat melakukan penelitian pada populasi yang lebih besar atau menyelidiki variabel lain yang dapat berinteraksi dengan variabel pemecahan masalah Polya, penelitian ini dapat dijadikan sebagai salah satu referensi.

\section{DAFTAR PUSTAKA}

Abidin, Z. 1989. Pemecahan Masalah Polya dalam Belajar Matematika. Tesis, PPs IKIP Malang.

Abidin Syamsuddin. 2003. Psikologi Pendidikan, Bandung : PT Remaja Rosda Karya

Arum Handini Primandari. 2010. Upaya Meningkatkan Kemampuan Pemecahan Masalah Siswa Kelas VIIIa SMP N 2 Nanggulan Dalam Pembelajaran Matematika Pokok Bahasan Bangun Ruang Menggunakan Model Pembelajaran Kooperatif Tipe Think-Pair-Square. Skripsi. Jurusan Pendidikan Matematika Universitas Negeri Yogyakarta.

Muhtarom. 2012. Profil Kemampuan Pemecahan Masalah Mahasiswa yang Mempunyai Gaya Kognitif Field Independen(FI) pada mata kuliah kalkulus. Disampaikan pada seminar nasional matematika.

Nurdin. 2007. Model Pembelajaran Matematika yang Menumbuhkan Kemampuan Metakognitif untuk Menguasai Bahan Ajar. Ringkasan Disertasi. Surabaya: Universitas Negeri Surabaya.

Polya, George, 1985.How To Solve It 2nd ed. Princeton University Press: New Jersey

Suharsimi Arikunto. 2006. Prosedur Penelitian Suatu Pendekatan Praktik. Jakarta: PT Rineka Cipta.

Suherman. 2003. Strategi Pembelajaran Matematika Kontemporer. Bandung-JICA. Universitas Pendidikan Indonesia UPI.

Sugiyono. 2012. Metode Penelitian Pendidikan (Cet XV). Bandung: Alfabeta.

Sukardi. 2003. Metodologi Penelitian Pendidikan. (Cet.I). jakarta: Bumi Aksara.

Udin S. Winataputra, dkk. 2003. Strategi Belajar Mengajar. Jakarta : Pusat Penerbitan Universitas Terbuka W. Gulo. 2005. Strategi Belajar Mengajar Jakarta : Grasindo. 